\title{
HERBAL COMMUNITY: Another consideration about
}

\section{Pharmacognosy}

Shah Murad ${ }^{*}$, Saima Rafique², Abrar Umar ${ }^{3}$, Manal Raouf Mahar ${ }^{4}$, Palwasha Awan ${ }^{4}$, M Hyder Awan and Sibghatullah Sangi $^{6}$

${ }^{1}$ Professor of Pharmacology at Dr. Akbar Niazi Teaching Hospital- IMDC, Islamabad-pakistan

${ }^{2}$ AP Pharmacology at Wah Medical College, Rawalpindi Pakistan

${ }^{3} \mathrm{HOD}$, Community Medicine at Mohi-ud-Din Islamic University, Mirpur, AJK

${ }^{4}$ Dentist at IDH, Islamabad.

${ }^{5}$ paediatric department at BBH, Rawalpindi, Pakistan.

${ }^{6}$ Pharmacology Department, Northern Border University, Arar, Saudi Arabia.

*Corresponding Author: Shah Murad Mastoi Baloch, HOD Pharmacology and Therapeutics at Islamabad Medical College, and DANTH, main MURREE road, Islamabad-Pakistan.

Received date: August 25, 2020; Accepted date: August 28, 2020; Published date: October 16,2020

Citation: Murad S., Rafique S., Umar A., Manal R. Mahar, Awan P., M Hyder Awan and Sangi S.,(2020) herbal community: Another consideration about Pharmacognosy J, Pharmaceutics and Pharmacology Research 3(2); DOI: 10.31579/2693-7247/009.

Copyright: ( ) 2020, Shah Murad Mastoi Baloch, This is an open access article distributed under the Creative Commons Attribution License, which permits unrestricted use, distribution, and reproduction in any medium, provided the original work is properly cited.

\begin{abstract}
The metabolic disorders are main and increasing public-health and clinical challenge worldwide because of urbanization, excessive energy intake, increasing obesity, and sedentary life styles. According to International Diabetes Federation (IFD) diabetes is one of the major metabolic disorders and a dangerous risk factor for heart problems. Twenty five percent of the world's adults have metabolic disorders. Recently in year 2013 the American Heart Association also reported that adults have abnormal serum lipid profile. Allopathic drugs used as hypolipidemic agents have number of unwanted effects. Herbal therapy for Hyperlipidemia is getting attention due to their less frequent side effects. In this study we have compared hypolipidemic effects of Fenofibrate $40 \mathrm{mg}$ with Nigella sativa. Seventy five hyperlipidemic patients from National Hospital Lahore were enrolled for study. Consent was taken from all enrolled participants and were divided in three equal numbers ie; twenty five in each group. Group 1 was on Nigella sativa, group 2 was on Gemfibrozil and third group was on placebo therapy. They were advised to take drugs for two months. After completion of study pretreatment and post treatment values of LDL cholesterol were analyzed statistically. In 25 patients who were on Nigella sativa, their LDL cholesterol decreased from $191.14 \pm 3.45$ to $159.40 \pm 2.98 \mathrm{mg} / \mathrm{dl}$. 31.7 $\mathrm{mg} / \mathrm{dl}$ LDL reduction was observed when compared with placebo group. In 25 patients who were on Fenofibrate 40 $\mathrm{mg}$, their LDL cholesterol decreased from $197.77 \pm 3.91 \mathrm{mg} / \mathrm{dl}$ to $159.62 \pm 2.20 \mathrm{mg} / \mathrm{dl}$. LDL reduction in this group was $38.2 \mathrm{mg} / \mathrm{dl}$. These changes are highly significant with $\mathrm{p}$-values of $<0.001$. We concluded from this study that hypolipidemic characteristic of Nigella sativa is comparable and therapeutically as effective as traditionally used hypolipidemic medication Fenofibrate.
\end{abstract}

Keywords: lipids; metabolic syndrome; obesity; prevention; hyperlipidemia

\section{Introduction}

Persons with metabolic syndrome (MS) are twice as likely to die from, and thrice as likely to have a heart attack or stroke as compared with others. Type 2 diabetes mellitus is one of the most common chronic diseases in the whole world and the fourth or fifth leading cause of death in the developed countries; it accounts for 90 percent of all diabetes and has become one of the major causes of premature ill health and death mainly through the increased risk of cardiovascular disease (CVD) which is responsible for up to 80 percent of these deaths. As per a projection, there will be about 23.3 million deaths by CVD worldwide by 2030 [1]. Hyperlipidemia is one of the major reason for development of MS [2]. In human body free radicals are formed in consequence of various metabolic processes. If there is abundance of low density lipoprotein particles in plasma, there are chances of risk to develop CAD (coronary artery disease) when free radicals interact with LDL particles. CAD may lead to morbidity and mortality due to cardiac arrest in human population [3]. In some cases, atherosclerotic plaques may totally block the blood supply to the myocytes, causing cardiac attack [4]. Atherosclerotic plaque contains calcium, cholesterol, free fatty acids, and macrophages in variable amount. These plaques are of two types ie; hard and soft. Soft plaques are more vulnerable than hard and can rupture easily as compared to hard one. There are risks for ischemic stroke too if blood supply to neurons ensues [5]. Hypolipidemic drugs can be used to prevent hyperlidemia, CAD, heart arrhythmias and cardiac arrest. Allopathic drugs used to prevent or cure Hyperlipidemia include Statins, Fibrates, niacin and bile acid binding resins [6]. If Fenofibrate is used, there is increased synthesis of high density lipoprotein particles in plasma. In patients suffering from hyperlipidemia, Fenofibrate enhances turnover of tissue cholesterol, thus reducing lipoprotein particles. Apo proteins in LDL are also changed by Fenofibrates leading to high affinity for the low density lipoprotein receptors to LDL particles [7, 8]. Nigella sativa or kalonji contains conjugated linoleic acid, thymo-quinone, melanthin, nigilline, damascenine, and trans-anethole. Thymoquinone (TQ) extracted from 
Nigella sativa (kalonji) inhibits iron-dependent microsomal lipid peroxidation. Stimulation of polymorph nuclear leukocytes with thymoquinone works as protector against damaging effects of free radicles generated biochemically in human body $[9,10]$. Prehistorically Nigella sativa is being used to treat, inflammation, high plasma lipids, high blood pressure, asthma, diabetes mellitus, arthritis, and gastrointestinal problems $[11,12]$. Worldwide, the first curative line of metabolic disorder was non-pharmacologic actions consisted of diet and lifestyle changes as well as appropriate care in order to decrease mortality and morbidity of such diseases. However, the major concern for medical scientists to find pharmacologic approach, and to increase the efficacy of chronic drug treatment. Medical researchers do have tendency to find curative agents among traditional sources. As per World Health Organization (WHO) about 70 percent population of entire world depends upon traditional and folk medicines. In India, about 80 percent of the rural population depends upon traditional and folk medicines for their health care. In this respect, many plant extracts have been assessed for their efficacy in metabolic disorders and hyperlipidemia; the Kasni (Cichorium intybus) is one of them, having a long history of therapeutic use in traditional medicine for many diseases specially diabetes $[13,14]$.

\section{Patients \& method}

Design of research work: It was single blind placebo controlled study. VENUE: The research work was conducted at National Hospital Lahore, Pakistan from February to July 2019.

Sample size and inclusion criteria: 75 hyperlipidemic patients were enrolled whose age range was from 18 to 70 years. Well explained, written consent was taken from all participants.

Exclusion criteria: Hypothyroidism, peptic ulcer, diabetes mellitus type-I and type-2, any major cardiac, renal and hepatic illness.

Grouping and methodology: Enrolled patients were divided in three equal numbers i.e.; 25 patients in Group-1, 25 in Group-2, and 25 patients in Group-3. Baseline LDL -cholesterol of all patients was determined in Biochemistry laboratory of the hospital. Separate folder was designed for each enrolled patient, in which their personal data, medical history, laboratory reports, follow-up visit proforma were kept. Their plasma

LDL-cholesterol was calculated by Fried Wald formula ${ }^{7}$ (LDL-C $=$ Total cholesterol-(Triglycerides/5 + HDL-C). 25 patients of group-1 were advised to take eight grams of Kalonji (Nigella sativa) in two divided doses for two months. 25 patients of group- 2 were advised to use $40 \mathrm{mg}$ Fenofibrate tablets twice daily for two months. 25 patients of group-3 were advised to take Capsule (Placebo capsule containing grinded wheat powder) twice daily for two months. They were advised to take their medication after breakfast and after dinner. All participants were convinced to go for 20 minutes brisk walk at morning or evening time. Fortnight follow up visit was arranged for all participants. After two months research period their lipid profile was determined in same laboratory of the hospital.

Statistical Analysis: Mean values of LDL-cholesterol \pm SEM were analyzed statistically by using SPSS 2014 version. Paired t-test was applied to analyse pre-treatment and post treatment values. $\mathrm{p}<0.05$ was minimum probability value to determine statistical significance. $\mathrm{p}<0.05$ was considered as non-significant change in tested parameter. $p>0.001$ was marked as highly significant change in the tested parameter.

\section{Results}

When results were compiled and statistically analyzed, it was observed that Nigella sativa and Fenofibrate $40 \mathrm{mg}$ decreased LDL-cholesterol significantly. Nigella sativa decreased LDL cholesterol from 191.14 \pm 3.45 $\mathrm{mg} / \mathrm{dl}$ to $159.40 \pm 2.98 \mathrm{mg} / \mathrm{dl}$. This change in mean values was $31.7 \mathrm{mg} / \mathrm{dl}$ with highly significant $\mathrm{p}$-value of $<0.001$. Fenofibrate decreased LDL cholesterol from $197.77 \pm 3.91 \mathrm{mg} / \mathrm{dl}$ to $159.62 \pm 2.20 \mathrm{mg} / \mathrm{dl}$. In mean values this change was $38.2 \mathrm{mg} / \mathrm{dl}$ with highly significant $\mathrm{p}$-value of $<0.001$. Placebo group showed LDL cholesterol reduction from $163.10 \pm 1.45 \mathrm{mg} / \mathrm{dl}$ to $159.40 \pm 1.77 \mathrm{mg} / \mathrm{dl}$. This change in mean values was $3.7 \mathrm{mg} / \mathrm{dl}$, with non-significant $\mathrm{p}$-value of $>0.05$.

\begin{tabular}{|l|l|l|l|l|}
\hline Drug & At day-0 & At day-60 & Change in mg/dl & p-values \\
\hline NS & $191.14 \pm 3.45$ & $159.40 \pm 2.98$ & 31.7 & $<0.001$ \\
\hline FF & $197.77 \pm 3.91$ & $159.62 \pm 2.20$ & 38.2 & $<0.001$ \\
\hline PL & $163.10 \pm 1.45$ & $159.40 \pm 1.77$ & 3.7 & $>0.05$ \\
\hline
\end{tabular}

Abbreviations: NS stands for Nigella sativa, FF stands for Fenofibrate, PL stands for placebo group. All parameters are measured in mg/dl, P-value $<0.01$ stands for significant change, $\mathrm{P}$-value $>0.05$ stands for non-significant change.

Table 1 illustrating LDL-cholesterol values before and after treatment with Nigella sativa, Fenofibrate $40 \mathrm{mg}$ and placebo with their p-values.

\section{Discussion}

Normal plasma lipid levels are required to keep heart healthy. Statins, Fibrates, Bile Acid Binding Resins, and Niacin (Vitamin B3) are used as hypolipidemic medicines in allopathy, but all these have unwanted effects. In Ayurveda discipline of therapeutics, various herbs, fruits and vegetables are used to reduce bad-cholesterol (LDL-C) and to increase good-cholesterol (HDL-C). In various research study results Kalonji is labeled as hypolipidemic therapeutic agent but little research work is done on comparison of its hypolipidemic potential with allopathy related hypolipidemic medicines. This research was targeted to compare its hypolipidemic characteristics with one of the Fibrate i.e. Fenofibrate 40 $\mathrm{mg}$. In our results it was observed that Kalonji or Nigella sativa reduced LDL-cholesterol $31.7 \mathrm{mg} / \mathrm{dl}$ which is almost $16.58 \%$ reduction in the parameter. This change is highly significant $(\mathrm{p}<0.001)$. Same highly significant change $(\mathrm{p}<0.001)$ was observed by using Fenofibrate $40 \mathrm{mg}$ in 25 hyperlipidemic patients. Results of study conducted by Osenda M et al [15] also support our observation and results. Fandelaki I et al [16] observed that Kalonji increase HDL-cholesterol, and decrease LDLcholesterol, triglycerides, and plasma total cholesterol in 4 weeks therapy if brisk walk is added with this medication. Alberti K et al [17] stated that there are various mechanisms by which seeds of the herb decrease LDLcholesterol and decrease triglycerides. Duverger A et al [18] explained

that NS inhibit enterohepatic circulation, leading to decreased synthesis of cholesterol by HMG-CoA reductase pathway. Harnandez M et al [19] observed lesser hypolipidemic effects of Kalonji when used in 15 hyperlipidemic patients for two weeks. They recommended to use herb for prolonged time as lipoproteins and their structural Apo proteins take time to be synthetize in hepatic cells. Harnandez M et al [20] had 
explained that kalonji is useful for increasing HDL-cholesterol. Haddad $P$ et al [21] wrote in their article that kalonji decrease plasma TG (triglycerides) rich lipoproteins (VLDL), thus neutral fat is reduced. Exchange of neutral fats between high density lipoproteins and very low density lipoproteins in plasma occurs by use of Kalonji [22].

\section{References}

1. Akazawa A, Nishikawa K, Suzuki K et al. (2002) Induction of apoptosis in a human breast cancer cell overexpressing RrbB-2 receptor by alpha-tocopheryloxybutyric acid. Jpn J Pharmacol; 89:417-21.

2. Salganik RI. (2001). The benefits and hazards of antioxidants. Controlling apoptosis and other protective mechanisms in cancer patients and the human population. J Am Coll Nutr; 20464S472 S.

3. Sumeet S Chugh, Kyndaron Reinier, Carmen Teodorescu et al. (2008) Epidiomology of sudden cardiac death: Clinical and research implications. Prog Cardiovas Dis; 51(3):213-28.

4. Bardy GH, Lee KL, Mark DB et al. (2008) Home use of automated external defibrillators for suden cardiac arrest. N Engl J Med; 358(17):1793-804.

5. Kathryn Moore, Frederick Sheedy, Edward Fisher. (2013) Macrophages in atherosclerosis: a dynamic belance. Nat Rev Immunol; 13(10):709-21.

6. SY Pan, H Dong, BF Guo et al. (2011) Effective kinetics of schisandrin $\mathrm{B}$ on serum/hepatic triglyceride and cholesterol levels in mice with and without influence of fenofibrate. Naunyn-Schmiedeberg's Archieves of Pharmacology; 383(6):585-91.

7. Boudewijn Klop, Jan Willem F Elte, Manuel Castro cabezas. (2013) Dyslipidemia in obesity: Mechanisms and potential targets. Nutrients; 5(4):1218-40.

8. M John Chapman, Henry N Ginsberg, Pierre Amarenco et al. (2012) Triglycerides-rich lipoproteins and high density lipoprotein cholesterol in patients at high risk of cardiovascular disease: evidence and guidance for management. Er Heart Jou; 32(11):1345-61.

9. Aftab Ahmad, Asif Husain, Mohd Mujeeb et al. (2013) A review on therapeutic potential of Nigella sativa: A miracle herb. Asian Pac J Trop Biomed, 3(5):337-52.
10. Bourgou S, Pichette A, Marzouk B, Legault J. (2012) Antioxidant, anti-inflammatory, anticancer and antibacterial activities of extracts from Nigella sativa plant parts. J Food Biochem; 36(5):539-46.

11. Harzallah HJ, Gravaa R, Kharoubi W et al. (2012) Thymoquinone, the Nigella sativa bioactive compond, prevents circulatory oxidative stress caused by 1,2-dimethylhydrazine in erythrocyte during colon postinitiation carcinogenesis. Oxid Med Cell Longev 2012:8540-65.

12. Kanter M, Akpoolat M, Aktas C. (2009) Protective effects of the volatile oil of Nigella stiva seeds on bet acell damage in streotocin-induced diabetic rats: a light and electron microscopic study. J Mol Histol; 40(5-6):379-85.

13. Benhaddou-Andaloussi A, Martineau L, Vuong T et al. (2011) The in vivi antidiabetic activity of Nigella stiva mediated through activation of the AMPK pathway and increase muscle glut4 content. Evid Based Complement Alternat Med; 5386-71.

14. Gokce A, Oktar S, Koc A, Yonden Z. (2011) Protective effects of thymoquinone against methotrexate-induced testicular injuiry. Human Exp Toxicol; 30(8):897-903.

15. Osende M, Jhajh S, Loraka Y, Simvan T. (2013) Antioxident Herbs. Jou Cl Nut Res; 16(5):99-104.

16. Fandelaki I, Marinah T, Mahassine N, Datau E. (2013) Chinese plants and Allopathy. Indo Med Jou; 102(61):122-9.

17. Alberti K, Gunith S, Haas M, Jhajh L. (2010) Statins and Fibrates: Comparision with Herbal plants. Jou Gastro Rev; 7(3):88-90.

18. Duverger A, Ismail M, Collins R, Ragheb A, Berrada Y. (2010) Phytochemistry of asthetic plants. UJPR; 6(3):77-83.

19. Harnandez M, Khuwarh M, Jorge R, Barret C. (2009) Antiatherogenic potential of kalonji seeds. Biochem Res; 5(6):33-8.

20. Haddad P, Setaff A, Neural C, Mahon S. (2014) HMG-CoA reductase inhibitor plants. Pertanika Jou Sch Res Rev; 14(6):669.

21. Grundy SM, Setaff AA, Packard CU, Shephered JM. (2014) Lipid lowering effects of kalonji. J Plants Res; 8(6):67-72.

22. Wong NC, Naem EE, Lordu YI, Mcdusa VE, Assi MA. (2012) How do plants work in therapeutics? J Cl Micr, 16(7):89-94.

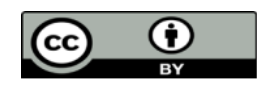

This work is licensed under Creative Commons Attribution 4.0 License

To Submit Your Article Click Here: Submit Article

DOI: $10.31579 / 2693-7247 / 009$
Ready to submit your research? Choose Auctores and benefit from:

* fast, convenient online submission

* rigorous peer review by experienced research in your field

* rapid publication on acceptance

* authors retain copyrights

* unique DOI for all articles

* immediate, unrestricted online access

At Auctores, research is always in progress.

Learn more www.auctoresonline.org/journals/pharmaceutics-andpharmacology-research 